\author{
Anastasiia Kuznietsova \\ $\mathrm{PhD}$ in Linguistics \\ Université Sorbonne Paris Cité \\ ORCID ID 0000-0002-7256-8215 \\ anastasiia.kuznietsova@gmail.com
}

\title{
SECONDARY DESIGNATIONS OF NATIONALITIES IN MODERN UKRAINIAN AS ONE OF THE SIGNS OF NATIONAL IDENTITY AND A MANIFESTATION OF ETHNOCENTRISM
}

\begin{abstract}
The purpose of this article is to investigate secondary designations of nationalities of a pejorative type in modern Ukrainian, using material from fiction, scientific sources and lexical dictionaries. On the basis of the collected material, we analyzed these designations as one of the aspects of the national identity shaping, as well as the negative side of this phenomenon - ethnocentrism. The analysis revealed extralinguistics and linguistic factors that influenced the formation of the Ukrainian vocabulary of this segment - history, culture and cultural-linguistic interaction within different ethnic groups in Ukraine and abroad. The studied designations are identified, and classified within the aspect of ethnic and national identity in a way suitable for the understanding of a non-Ukraian speaking reader. The study also shows how these designations specific to the Ukrainian people having, for the most part, folk origins, can acquire individual traits in the creative laboratory of a writer, undergo an individual transformation, and reflect the personal position of an artist in his art.
\end{abstract}

Keywords: designations of nationalities; pejorative; national identity; ethnocentrism; ethnophobism; dysphemism.

\section{INTRODUCTION}

In this article, we look at secondary designations of nationalities in Ukrainian literary texts written between the end of the $18^{\text {th }}$ century to the present day. Since these designations are at a great extend ethno-specific, they reflect the cultural background of each people and, as a rule, are fully understandable only for native speakers. We can see that almost all the designations collected during this research somehow reflect the material and spiritual culture of Ukrainian speakers as well as their ethnic identity.

It should also be noted that, for a non-Ukrainian speaker, the perception of Ukrainian designations of this type turns to be difficult as they are specific to a culture in which they appeared. Thus it makes actual to conduct the study of such designations adapted for a foreign auditory.

The relevance of this research subject has been reflected in the works of English, American and Ukrainian sociolinguists and ethnologists, including William Sumner, Allan and Kate Burridge, Lars Andersson, Peter Trudgill, Lesâ Stavic'ka, Vitalij Žajvoronok, Oleksandr Taranenko and others who distinguish several aspects of the pejorative designations of persons, including historic and social.

However, these works contain only fragmentary references on the national identity aspect and those which are written in Ukrainian are consultable only by Ukrainian speakers.

\section{METHODS}

The research paradigm was interpretive, which placed emphasis on the analysis of the sources as well as the synthesis of the obtained results. In addition to the dictionaries (Encyclopedic Dictionary of Symbols of Culture of Ukraine (2015); Žajvoronok Dictionary of Signs of Ukrainian Ethnic Culture (2006) online; Academic dictionary of the Ukrainian language (1970-1980) in 11 volumes online; Small online glossary of Ukrainian žargon (2003) by Stavic'ka; Dictionary of obscene lexicon and its analogues (2008) by Stavic'ka, we also researched into the literary texts. 


\section{RESULTS AND DISCUSSION}

Every culture reflects the worldview of nation, its national consciousness, peculiarity of philosophical thinking and understanding of the basic problems of global and own being. Thus the Ukrainina culture embodies the ethical ideals of the Ukrainian people, their views on social and personal life, embodied images and concepts that are enshrined in the national language, traditions, norms and customs.

Ukrainian culture and the worldview of the Ukrainian people in general have been influenced by many external and internal factors. External factors include the long colonization period of Ukraine and its geographical location. The result of the mutual influence of different cultures on the territory of the country has become a new way of worldview, which has been etched in the outlook, psychology, customs and traditions of the Ukrainian people. "Ukrainian culture is one of the areas where the elements of the "contemplative, introverted" culture of the East and the "practical, extroverted" culture of the West are organically united with the authentic culture of Ukrainians and give a unique fusion of their material and especially spiritual manifestation" (Savina, 2008).

Analyzing the names of nationalities in the Ukrainian language, we should first explain the concept of national identity and ethnocentrism.Thus, Nagorna (2012) defines national identity as a broad complex of individualized and non-individualized interpersonal connections and historical representations, which is the basis of self-identification of individuals and groups of people with a distinct identity, historical memory, culture, myths, traditions, objects of worship, national idea.

Ethnocentrism is interpreted as a belief in the supremacy of its own ethnic group and its culture in comparison with others. This concept was introduced in 1906 by W. Sumner, who understands ethnocentrism as a vision of things, in which some group is at the center of everything, and all others are compared with reference to it (Bizumic, 2014, p. 3). Such a mechanism, on the one hand, helps a person to preserve his identity, and on the other hand, is an obstacle to interethnic relations and interactions. The commitment of one's group can be combined with a tolerant attitude towards other ethnic communities. However, problems may arise when members of one community begin to impose their values on others.

There is another type of ethnocentrism - when individuals not only prefer their group and impose their values, but also view representatives of other ethnic groups as inferior and maximize intergroup differences. It is with this kind of ethnocentrism that we associate the emergence of numerous pejorative nominations (dysphemisms) to designate persons belonging to other races, nationalities or ethnic groups (including Ukrainians themselves) in modern Ukrainian.

Although offensive means of nomination are replaced by politically correct lexical units, any new politically correct name (euphemism) eventually becomes pejorative as a result of the acquisition of negative attributes (becomes dysphemism).

Thus, in English and American literature of the nineteenth century the word "negro" or "nigger" had a neutral meaning (Mosiêvič, 2014), which gradually acquired a vulgar and discriminatory connotation. In the late twentieth - early twentieth centuries due to some transformation (negro - colored - black), the term "Afro-American" started to be used (ibid).

Until the collapse of the Soviet Union, lexeme негp (negr) ('negro') was neutral in the Ukrainian language, denoting "the indigenous population of tropical Africa, which has a dark skin color, as well as descendants of Africans in America: Прислужниці арабки, туркені, негритянки $\check{u}$ украӥнки розносять кофе, фрукти й шербети (Arab, Turk, Negros and Ukrainians deliver coffee, fruits and sherbet) (Nečuj-Levic'kij, II, 1956, p. 446); Негр порівнює улюблену дівчину зі стрункою пальмою (A пеgro compares his beloved girl to a slender palm tree) (Ril's'kij, III, 1956, p. 133).

At the present stage, in Ukrainian euphemistic vocabulary (which, however, depending on the context can also be used in the function of dysphemisms), includes such nominations as: афроамериканець (afroamerikanec') ('African American'), темношкірий (temnoškìij) ('black') (Stavic'ka, 2003).

However, the largest number of dysphemistic nominations were recorded with regard to the nations whose representatives reside in the neighboring countries, as well as Jews who lived in Ukraine in large numbers since the Medieval ages. 
Thus the nomination "Jew" has one of the largest list of synonyms in the dictionary of

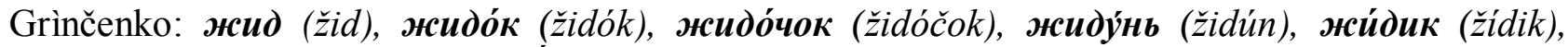
жидюгá (židûgá), жнидя́ка (židấka) (Dictionary of Ukrainian in 4 vols., 1907-1909, p. 483), as well as in the dictionary of Ukrainian jargon: абраша (abraša), аїठ (аїd), маланець (malanec'), «щирий українець» (sirij ukraïnec') (Stavic'ka, 2003). The ironic nomination «щирий українець» ('genuine Ukrainian') is probably due to the fact that Jews as a foreign nation has always been subtly aware of changes in political vectors, and with Ukraine's proclamation of independence was one the first to learn and use Ukrainian in official communication.

Such a large number of derivatives of the word «жид» (žid) (pej. 'Jew') is explained by the fact that this nomination was considered normative and widely used in oral language, business documents and court decisions. The negative connotation was attributed to this nomination after the revolution of 1917. Even in the Academic Dictionary of the Ukrainian Language (1971) two meanings are attributed to this lexeme: 1. Obsolete, the same as the Jews: A жюид старий Ніби теє знає, Дочку свою одиноку В хаті замикає (And the old Jew seems to know, and encloses his lonely daughter in the house) (Ševčenko, II, 1953, p. 158). 2. The insulting name of the Jews (Dictionary of Ukrainian, vol. 2, p. 528).

With regard to Russians, the most ancient pejorative ethnophobism should be considered кацап (kасар): Прийшли кацапи обідати, посміялися з неї, хоч вона того й не пойняла (Katsaps came for lunch, laughed at her, though she did not understand) (Mirnij, I, 1954, p. 67).

Max Fasmer in the Etymological Dictionary (1973, p. 123) states that кaцan (kacap) means «як цап» (âk cap) ("as a buck") because of the beard which was worn earlier by Russians which reminded goat to Ukrainians. According to Ukrainian scholars Krymskyj and Javornytskyj the word has Turkish roots, since kassap is translated as "butcher". There are also many derivative words: «кацапія» (kacapiâ), «кацапурія» (kacapuriâ), «кацапетовка» (kacapetovka) (a dysphemistic name of Russia) (Etymological dictionary of Ukrainian language, p. 408).

Actualization of the pejorative word москаль (moskal') (moscovite) (pej. Russian) (polish by origin) with the hostile connotation occurred in line with the actualization of some other words from the region of the former Polish Ukraine, however this example is much more commonly used in the spoken language nowadays.

Among the first writers which started to use this word in Ukrainian-language discourse to name Russians is Shevchenko:

Кохайтеся, чорнобриві, / Та не з москалями, / Бо москалі - чужі люде, /Роблять лихо з вами. / Москаль любить жартуючи, Жартуючи кине; / Піде в свою Московщину, / А дівчина гине ... (Make love, black-eyed girls, / But not with moscovites, / Because moscovites are strangers, / They will do evil with you. / Moscovite loves by joke, and by joke will dump you; / Will go to his Muscow-state / And the girl will die ...)

On a nation-wide scale, the pejorative lexeme москаль (moskal') was actualized in 19801990s, mainly with an ironic connotation (not only in Russia itself and in Russian discourse in Ukraine, as well as in certain Ukrainian-speaking circles), which appeared to be ironic image of "damn Muscovites", from which all Ukraine's misfortunes are alleged: Слоника замучили кляті москалі, / похилився хоботом слоник до землі...» (The elephant was tortured by the damn Muscovites, / and he bowed to the ground ...) (Pozaâk, The Elephant Duma).

The more insulting variant of dysphemism to name Russians - кацаn is less popular, first of all, because it has a purely ethnic, and not 'ethnic-state' meaning and is used to refer to ethnic Russians living in Ukrainian cities and in compact villages as well as with regard to recent newcomers from Russia, who are noticeably differ from the "Ukrainian" Russians) (Nakonečeij, 2004, p. 308-306).

Since the beginning of the annexation of Crimea and the military conflict between Russia and Ukraine, the use of traditional "unofficial" names of Ukrainians and Russians has intensified (not only with respect to ethnic Ukrainians, but more broadly to the population of Ukraine). The most ancient disphemism-ethnophobism against Ukrainians is хохол (khokhol) / хахол (hahol) (crest), which is interpreted in the Academic Dictionary of Ukrainian as "a pejorative name of a 
Ukrainian": - Ну, ти, хохол. Все тобі смішки, - Андрій Єрмолаєв явно заздрить благодушності Гладкого (Well, you, hohol. Everything is ridiculous to you, - Andrìj Êrmolaêv clearly envies the smoothness of Gladkij (Dovženko, 1957, p. 415).

In the territory of the Northern Ukraine, this name gradually became familiar (not least, of course, due to the lack of a common ethnonym for Ukrainians for a long time), for example, in the memoirs of Ukrainian writer Oleksandr Dovženko about his childhood: «-Tamy! - Що, синку? Що там за люди пливуть? - То здалека, орловські. Руські люди, з Росії пливуть. - А ми хто? Ми хіба не руські? - Ні, ми не руські. - А які ж ми, тату? Хто ми? - А хто там нас знає. Прості ми люди, синку. Хахли, ті, щуо хліб обробляють. Сказати б, мужики ми...» (- Dad! What, son? - What are the people swimming there? - They are from Orel. They are Russian people. - And who are we? Are we not Russians? - No, we are not Russians. - And what are we, Dad? Who are we? - Who knows. We are just simple humans, son. Hahli - those who make the bread. So to say" (Dovženko, 1957).

Newly created disphemisms укри (ukry), укропи (ukropi) in their meaning are somewhat different from the traditional хахли (hahly), which is associated with some changes in the perception of the Ukrainian nation by Russians, which occurred in the process of the current war. In the minds of Russians, the word хахол (hahol) is associated with inferior type ethnicity which uses a ridiculous language that gives them the impression to be a perverted Russian language. Sо хахол means an inferior type, dull simpleton, albeit cunning, ideally suited to the role of a clown, capable to tolerate endless mocking as being a coward - he will endure everything for material gain.

The other pejorative nomination of Ukrainians - yкpon (ukrop) (dill) has an additional negative connotation, since it evokes in the minds of Russians the homonymic name of a plant, and the significance of this plant in everyday life is quite trivial in comparison with the main garden crops, tomatoes, etc. This "insignificance" of dill as a plant enhances the semantic component of superficiality. Its derivational variant - the pejorative nomination укропітек (ukropitek) hints by its second part on the origin of the chimpanzee, and $\boldsymbol{y \kappa p}(u k r)$ is simply the pejorative reduction from украинец (ukrainec) (Ukrainian). As a certain phenomenon, one should consider the fact that the described pejorative nominations of the residents of Ukraine are used not only by "neighboring" people, but also by Ukrainians themselves.

In Ukrainian literary texts we also find a wide range of dysphemisms to name Poles. Thus the spread of the words лях (liah) (m. pole) and ляшка (liashka) (f. pole) dates back to the nineteenth century and is consistently used in Ukrainian literature of the twentieth century: Отож у клечальну неділю їх і повінчано обох, Таки в домашньому костьолі. Вони ляхи були (So on Sunday, they were married in the home church. They were lâhs) (Shevchenko, II, 1953, p. 64); Музикy послухаю. Там є одна стара ляшка, щзо дуже гарно грає з Шопена (I will listen to the music. There is an old lâška playing Chopin very well (Kocûbins'kij, III, 1956, p. 193). In the Academic Dictionary, these lexemes do not contain the mark "pejorative", but only - "historicism". However, their later replacement by the common used word поляк (polâk) (pole) added an offensive tone to above mentioned dysphemisms.

In addition, the Dictionary of slang gives other examples of pejorative lexemes to designate the representatives of Poles: бзденик (bzdenik), зденек (zdenek), пиек (pšek) (these names reflect the characteristic features of the phonetics of the Polish language) (Dictionary of the Ukrainian Language in 11 volumes, vol. 6, 1975, p. 450).

In studied dictionaries we have also found a wide range of ethnophobisms concerning persons of the following nationalities:

Azerbaijanis: азер (azer), айзер (ajzer), айзербон (ajzerbon);

- Caucasian nations (Chechens, Georgians): xaч (hač): До нас підсів якийсь апокаліптичний хач / обізвав Джевуса йогом <... (Some apocalyptic hač sat aside us / and called Jevus a yogi <...> (Коваленко, Молоде вино - Kovalenko, Young wine); чорножсопий (с̌оrnоžopij)(black assed): - Давно пора показати ц̧им чорножопим, хто zocnoдар y мicmi <...> (It is time to show to these black assed people who is the master of the city... > (Кокотюха, Повернення сентиментального гангстера - Kokotuha, Return of 
the Sentimental Gangster); цурбан (с̌иrban): Саме це дозволило Стасові відкинути останні вагання. Він уб'є Басмача, изього чурбана, худобину вузькооку (This is what allowed Stasov to drop his last hesitation. He will kill Basmač, this churban, this narroweyed cattle (Kokotuha, 1991);

- Representatives of Asian people: чурка (čurka), урюк (urûk), чурбак (čurbak), вузькоокий (vuz'kookij) ("narrow-eyed"): Саме ие дозволило Стасові відкинути останні вагання. Він уб'є Басмача, цього чурбана, худобину вузькооку (This is what allowed Stasov to drop his last hesitation. He will kill Basmač, this churban, this narrow-eyed cattle (Kokotuha, 1991).

The appearance of the mentioned pejorative lexemes is an evidence of a negative attitude towards the representatives of the respective nations, which is manifested in the hint on skin and hair color, poor mental abilities, or the name of the fruit, which is usually traded by representatives of the relevant nationalities (урюк (urûk) - apricot).

\section{CONCLUSIONS AND SCOPE FOR FURTHER RESEARCH}

Pejorative nominations of representatives of different nationalities is a verbal manifestation of ethnic prejudices, based on hetero-stereotypes and express the attitude of persons of one ethnosocial community to representatives of another ethnic group. Therefore, the fragments of ethnosocial reality, values, hetero-stereotyped representations and beliefs of representatives of one nation about the other are fixed in nominations of foreigners. Reflection of ethnic prejudice is manifested in the use of dysphemisms with regards to foreigners. Thus, dysphemisms denoting representatives of other nationalities are structures that contain stereotypical, evaluative and ideological components.

In conclusion, it should be said that this work intends to set a new milestone in the field of ethnical and linguistic identity studies and its exploration must be continued.

We could imagine developing this work by expanding the sample of lexical entries to a volume of complete dictionary in reverse - English-Ukrainian; or even a bidirectional EnglishUkrainian, Ukrainian-English dictionary. This may expend the study of euphemisms / dysphemisms also in the texts of English literature.

It would also be interesting to carry out a further study from the point of view of the native speakers - to study their motives for using these figures of speech in different situations.

\section{REFERENCES}

Allan K., \& Burridge, K. (1991). Euphemism and Dysphemism: Language Used as Shield and Weapon. New York: Oxford University Press.

Allan K., \& Burridge, K. (2006). Forbidden Words. Taboo and the Censoring of Language. Cambridge: Cambridge University Press.

Andersson, L, \& Trudgill, P. (1990). Bad Language. London: Penguin Books.

Bilodid, İ. (Ed.). (1970-1980). Slovnik ukraïns'koï movi: v 11 tomah [Dictionary of the Ukrainian language: in 11 volumes]. Retrieved from http://sum.in.ua/ [in Ukrainian]

Bizumic, B. (2014). Who Coined the Concept of Ethnocentrism? Journal of Social and Political Psychology, 2(1), 3-10.

Dovženko, O. (1957). Zacharovana Desna [Enchanted Desna]. Dnipro Publishers. [in Ukrainian]

Fasmer, M. (1996). Etimologičeskij slovar' russkogo âzyka [Etymological dictionary of Russian]. St. Petersbourg. [in Russian]

Grìnčenko, B. (Ed.) (1907-1909). Slovar' ukrä̈ns'koï movi: v 4-h tomah [The Dictionary of the Ukrainian language: in 4 volumes]. Kyiv. [in Ukrainian]

Grìnčenko, B. (Ed.). (1958). Slovar' ukraïns'koï movi: v 4-h tomah [The Dictionary of the Ukrainian language: in 4 vols]. Vol. 1. K.: Publishing House of the Academy of Sciences of the Ukrainian SSR. [in Ukrainian]

Kokotuha, A. (1991). Marriage Games of Frogs. Kyiv.

Mel'ničuk, O. (Ed.). (1982-2012). Etimologičnij slovnik ukraïns'koï movi u 7-mi tomah [Etymological dictionary of the Ukrainian language in 7 volumes]. Vol. 2. NAS of Ukraine. Institute of History of Ukraine. K.: "Naukova dumka". [in Ukrainian]

Mosiêvič, L. (2014). Kognitivna ta komunikativna sutnist' evfemizmìv ta disfemìzmìv v anglomovnomu prostorì. [The cognitive and communicative nature of euphemisms and dysphemisms in the English-speaking space]. Retrieved from http://www.nbuv.gov.ua/portal/Soc Gum/Dtr_gn/2008 1/files/GN108 10.pdf [in Ukrainian] 
Nagorna, L. P. (2012). Istorychna pamyat': teorii, dyskyrsy, refleksii [Historical memory: theories, discourses, reflections]. Kyiv. [in Ukrainian]

Nakonečnij, Ê. (2004). Ukradene ìm'â: Čomu rusini stali ukrä̈ncâmi. L’viv. [in Ukrainian]

Ovsiênko, V. (2010). Sindrom "nedoukraïncâ" [Syndrome of "nedoukrainets"]. In O. Taranenko (Ed.) Ukrä̈ns'korosìjs'ki movni kontakti na sučasnomu etapì: protâguvannâ i vìsštovhuvannâ. İ. Vplivi, interferenciâ, zapozičennâ [Ukrainian- Russian language contacts at the present stage: stretching and repulsion. I. Impacts, interference, borrowing]. Movoznavstvo [Linguistics], 2-3. [in Ukrainian]

Pogribnij, A. (1999). Âkbi mi včilis' tak, âk treba Rozmovi pro nabolile [If we learned as it should be: Talk about sore]. Kyiv. [in Ukrainian]

Savìna, M. (2008). Nacional'na tradiciâ šlûbno-sìmejnih stosunkìv [National tradition of marriage and family relations]. Retrieved from http://bratstvolviv.orthodoxy.ru/trad.html [in Ukrainian]

Smolìj, V. (2018). (Ed.). Enciklopediâ istorï Ukrä̈ni: Ukrä̈na - Ukrä̈ncì [Encyclopedia of Ukrainian History: Ukraine - Ukrainians]. Vol. 3. NAS of Ukraine. Institute of History of Ukraine. K.: "Naukova dumka". [in Ukrainian]

Stavic'ka, L. (2003). Korotkij slovnik žargonnoï leksiki ukraïns'koï movi [A short dictionary of the Ukrainian language jargon]. K.: Critics. Retrieved from http://ukr-zhargon.wikidot.com/peredmova [in Ukrainian]

Stavic'ka, L. (2008). Ukraïns'ka mova bez tabu. Slovnik necenzurnoï leksiki ta ï̈ vidpovìdnikì. Obscenizmi, evfemizmi, seksualizmi [Ukrainian Without Taboos: A Dictionary of Obscenities, Euphemismes and Sexual Slang]. K.: Krytyka. [in Ukrainian]

Sumner, W. (1906). Folkways: A study of the sociological importance of usages, manners, customs, mores, and morals. Boston, MA: Ginn and Company.

Taranenko, O. (2010). Ukraïns'ko-rosìjs'kì movnì kontakti na sučasnomu etapì: protâguvannâ ì vìdštovhuvannâ. Ì. Vplivi, ìnterferenciâ, zapozičennâ. (Ukrainian-Russian language contacts at the present stage: stretching and repulsion. I. Impacts, interference, borrowing). Movoznavstvo [Linguistics], 2-3. [in Ukrainian]

\begin{abstract}
Анастасія Кузнєцова. Дослідження вторинних позначень національностей пейоративного типу в сучасній українській мові. Метою даної статті $є$ дослідження вторинних позначень національностей пейоративного характеру в сучасній українській мові, використовуючи матеріали 3 художньої літератури, наукові джерела та словники. На основі зібраного матеріалу авторка аналізує ці назви, як один 3 аспектів вияву національної ідентичності українців, а також негативний бік цього явища - етноцентризм. Під час аналізу виявлено поза- та внутрішньомовні фактори, які вплинули на формування української лексики даного сегменту - історія, культура i культурно-мовна взаємодія в межах різних етнічних груп в Україні і за їі межами. Дослідження вторинних позначень національностей, їх ідентифікація і класифікація у світлі формування етнічної та національної ідентичності адаптовано для неукраїномовної аудиторії. У статті окреслено, як вторинні позначення національностей, що мають здебільшого розмовне походження, можуть набувати індивідуальних рис у творчій лабораторії письменника, зазнавати індивідуальної трансформації, відображати особисту позицію митця.
\end{abstract}

Ключові слова: вторинні позначення національностей; пейоративний; національна ідентичність; етноцентризм; етнофобізм; дисфемізм 